\title{
Effect of tumour associated tissue eosinophilia on survival of women with stage IB carcinoma of the uterine cervix
}

\author{
P B Bethwaite, L J Holloway, M-L Yeong, A Thornton
}

\begin{abstract}
Aims-To examine the survival of a group of women with stage IB invasive carcinoma of the uterine cervix, divided according to the expression of tumour associated tissue eosinophilia (TATE).

Methods-Histological material from 81 women with stage IB squamous and adenosquamous cervical carcinomas before radiotherapy was assessed for the extent of tissue stromal eosinophilia, quantified using antibodies to human major basic protein.

Results-Twenty eight (38\%) of the cases demonstrated TATE of over 30 eosino-

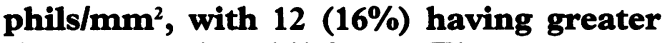
than 100 eosinophils $/ \mathrm{mm}^{2}$. Eleven women in the series developed distant spread or recurrent pelvic disease, this group having a stromal eosinophil density significantly less $\left(13.8 / \mathrm{mm}^{2}\right)$ than the remainder $\left(69.9 / \mathrm{mm}^{2}\right) \quad(p=0.03)$. The acturial five year survival rate for women with a tumour eosinophil density over $30 / \mathrm{mm}^{2}$ was $92 \%$ compared with $70 \%$ with a density under $30 \mathrm{~mm}^{2}$, with a significant difference in the survival curves for these two groups ( $p=0 \cdot 03$ ).

Conclusions-As a univariate parameter, a tumour associated tissue eosinophilia of at least modest proportions is associated with statistically improved survival in women with stage IB cervical carcinomas.
\end{abstract}

$(\Im$ Clin Pathol 1993;46:1016-1020)

Solid tumours are associated with a variable pattern of stromal inflammatory cell infiltration, usually characterised by a lymphoplasmacytic response. A heavy infiltrate is associated with improved prognosis in a number of tumour sites. ${ }^{1}$ Eosinophilic leucocytes are sometimes observed as a component of the stromal infiltrate, and a tumour associated tissue eosinophilia (TATE) is well described in a range of tumour types and sites, including carcinoma of the cervix, ${ }^{2-8}$ lung, ${ }^{9}$ gastrointestinal tract, ${ }^{1011}$ and in transitional cell carcinoma of the bladder. ${ }^{12}$ Previous work has suggested that TATE may also be associated with a better outlook. ${ }^{8}$

In the uterine cervix around $3 \%$ of cases show an intense TATE. These tumours, with a stromal eosinophil density of over $100 / \mathrm{mm}^{2}$, are easily recognised in routine histological sections. ${ }^{6}$ Some workers have reported an improved survival with "intense TATE",4613 while others find no apparent association. ${ }^{2714}$

More common, yet less well characterised, are cervical carcinomas with a mixed inflammatory infiltrate, which includes a lesser proportion of eosinophilic leucocytes, usually admixed with chronic inflammatory cells. This "moderate TATE" group with a tissue eosinophil density between 30 and $100 / \mathrm{mm}^{2}$ has not been included before when examining the effect of stromal eosinophilia on survival.

\section{Methods}

Women with FIGO (International Federation of Gynaecology and Obstetrics) stage 1B invasive carcinomas of the uterine cervix were abstracted from a larger series of women with invasive cervical cancers. This series was previously reviewed to examine the effect of tumour mucin production on prognosis, and the details are published elsewhere. ${ }^{15}$ In summary, the series was drawn from a clinicopathological register of 186 cases of invasive cervical cancer, stage $1 \mathrm{~B}$ and above, presenting to a regionally based gynaecology oncology service between 1980 and 1987 .

The series included 90 stage $1 \mathrm{~B}$ tumours (62 squamous cell carcinomas, 19 adenosquamous carcinomas, eight adenocarcinomas and one mesonephroid tumour). The 81 squamous and adenosquamous tumours were selected for the study. As radiotherapy is known to induce TATE, eight cases were excluded for study as only histological material after radiotherapy was available. The histological material before radiotherapy was reviewed from the remaining 73 cases and two representative blocks were selected from each case and the haematoxylin and eosin stained sections studied. The degree of the lymphocytic or plasmacytic stromal response was graded dichotomously as either minimal to scant, or moderate to heavy.

To assist with accurate quantification of eosinophil tissue density, sections were cut from the selected blocks and the avidin-biotin-peroxidase complex (ABC) method was used to demonstrate eosinophil major basic protein (MBP) immunohistochemically. ${ }^{16}$ Endogenous peroxidase was blocked with hydrogen peroxide, periodic acid, and potassium borohydride. Digestion in $0.1 \%$ trypsin was followed by overnight incubation at $4^{\circ} \mathrm{C}$ with the primary polyclonal antibody, anti-human MBP, donated by $\mathrm{Dr}$ Gleich, Mayo Clinic, at a dilution of 1 in 4000 . 
Visualisation was achieved by 3,3'diaminobenzidine tetrahydrochloride (DAB, Sigma No D-5637), with haematoxylin counterstaining. The number of positively staining cells in the densest region, usually at the advancing tumour edge, in 40 microscopic fields at 400 times magnification were counted. The field areas were determined using a calibrated grid and the eosinophil density expressed as number per square millimetre of tissue.

Lowe has defined intense TATE as an eosinophil density over $100 / \mathrm{mm}^{2}$, roughly corresponding to those cases reported by various workers as cervical carcinoma with pronounced stromal eosinophilia. ${ }^{6}$ Decreasing the threshold to 30 eosinophils $/ \mathrm{mm}^{2}$, however, includes tumours with a moderate infiltrate, which are often not initially recognised in routine sections. ${ }^{11}$ These cutoff points were chosen a priori for the current study.

The tissue eosinophil density was compared among the major clinical and pathological subgroups using the Mann-Whitney U test. Detailed survival information was available from the register; survival was calculated from the date of diagnosis to the date of last follow up, intercurrent death, or cervical cancer related death. Survival was analysed using the product limit method of Kaplan and Meier, ${ }^{17}$ with univariate parameters assessed using the log-rank test.

\section{Results}

Among the 73 cases studied, 67 were staged FIGO stage $1 B$, the remaining six as IB occult. The age range of the patients was 25 to 76 years, with a mean of 43.7 years. Fiftysix cases $(77 \%)$ were non-mucin producing squamous cell carcinomas, while the remain-

Table 1 Comparison of tissue associated tumour eosinophil density among univariate parameters (Mann-Whitney $U$ test)

\begin{tabular}{|c|c|c|c|c|}
\hline Variable & $n=$ & $\begin{array}{l}\text { Mean } \\
\text { eosinophil } \\
\text { density/mm } m^{2}\end{array}$ & $\begin{array}{l}\text { Test } \\
\text { statistic } \\
(Z)\end{array}$ & $p$ value \\
\hline $\begin{array}{l}\text { FIGO stage } \\
\text { B } \\
\text { BOC }\end{array}$ & $\begin{array}{r}67 \\
6\end{array}$ & $\begin{array}{l}60 \cdot 6 \\
69 \cdot 6\end{array}$ & 0.83 & 0.41 \\
\hline $\begin{array}{l}\text { Type } \\
\text { Squamous } \\
\text { Adenosquamous }\end{array}$ & $\begin{array}{l}56 \\
17\end{array}$ & $\begin{array}{l}58.4 \\
71.6\end{array}$ & $1 \cdot 28$ & $0 \cdot 20$ \\
\hline $\begin{array}{l}\text { Tumour width } \\
<30 \mathrm{~mm} \\
\geqslant 30 \mathrm{~mm}\end{array}$ & $\begin{array}{l}35 \\
38\end{array}$ & $\begin{array}{l}77 \cdot 3 \\
46 \cdot 8\end{array}$ & 0.23 & 0.84 \\
\hline $\begin{array}{l}\text { Depth of invasion } \\
<10 \mathrm{~mm} \\
\geqslant 10 \mathrm{~mm}\end{array}$ & $\begin{array}{l}50 \\
23\end{array}$ & $\begin{array}{l}55 \cdot 4 \\
74 \cdot 7\end{array}$ & 0.47 & 0.63 \\
\hline $\begin{array}{l}\text { Age at diagnosis } \\
\quad<40 \mathrm{y} \\
\geqslant 40 \mathrm{y}\end{array}$ & $\begin{array}{l}31 \\
42\end{array}$ & $\begin{array}{l}88 \cdot 9 \\
41 \cdot 2\end{array}$ & 1.83 & 0.07 \\
\hline $\begin{array}{l}\text { LCSI }^{\star} \\
\text { Present } \\
\text { Absent }\end{array}$ & $\begin{array}{l}23 \\
46\end{array}$ & $\begin{array}{l}52 \cdot 9 \\
68 \cdot 6\end{array}$ & 0.14 & 0.88 \\
\hline $\begin{array}{l}\text { Pelvic lymph nodes } \\
\text { Involved } \\
\text { Uninvolved }\end{array}$ & $\begin{array}{l}17 \\
47\end{array}$ & $\begin{array}{l}49 \cdot 8 \\
72 \cdot 5\end{array}$ & 0.47 & 0.64 \\
\hline $\begin{array}{l}\text { Advanced local and } \\
\text { Present } \\
\text { Absent }\end{array}$ & $\begin{array}{l}11 \\
11 \\
62\end{array}$ & $\begin{array}{l}13.8 \\
69.9\end{array}$ & 1.99 & 0.03 \\
\hline $\begin{array}{l}\text { Lymphocytic/plasm } \\
\text { Minimal/scant } \\
\text { Moderate/heavy }\end{array}$ & $\begin{array}{l}\text { strom } \\
34 \\
39\end{array}$ & $\begin{array}{r}5.9 \\
109.9\end{array}$ & 5.73 & 0.001 \\
\hline
\end{tabular}

^Lymphatic-capillary space invasion. ing $23 \%$ were adenosquamous tumours, as already defined by us to include "covert" mucin producing squamous cell tumours. ${ }^{15}$

The women were treated as follows: routine hysterectomy alone $\mathrm{n}=2$; Wertheim's hysterectomy alone $\mathrm{n}=16$; preoperative caesium/Wertheim's hysterectomy $n=43$; hysterectomy/postoperative radiation $n=9$; radiation only $n=3$. Details of the protocols are given elsewhere. ${ }^{18}$ Pelvic lymph node sampling was undertaken in 64 women, with 17 (27\%) having histologically confirmed nodal disease. Six of 73 women had evidence of subsequent distant metastatic disease (lung $\mathrm{n}=3$, brain $\mathrm{n}=1$, bone marrow $\mathrm{n}=1$, cervical lymph nodes $n=1$ ) or recurrent pelvic disease $\mathrm{n}=5$.

Quantification of eosinophilic infiltration for all cases showed a range from 0 to 542 eosinophils $/ \mathrm{mm}^{2}$ (mean (SD) 61.5 (115.5). Twenty eight (38\%) cases had an eosinophil density over $30 / \mathrm{mm}^{2}$, with $12(16 \%)$ having greater than $100 / \mathrm{mm}^{2}$.

Table 1 shows that there was no significant difference in stromal eosinophil density among different tumour subgroups defined on the basis of histological type, tumour size, depth of invasion or presence of vascular space invasion. Younger women seemed to have a higher stromal eosinophil density compared with older patients, but the difference did not reach significance. There was no significant difference in eosinophil density in tumours with or without pelvic lymph node metastases, but tumours which subsequently developed pelvic or distant disease had a significantly lower density than the remainder (fig 1).

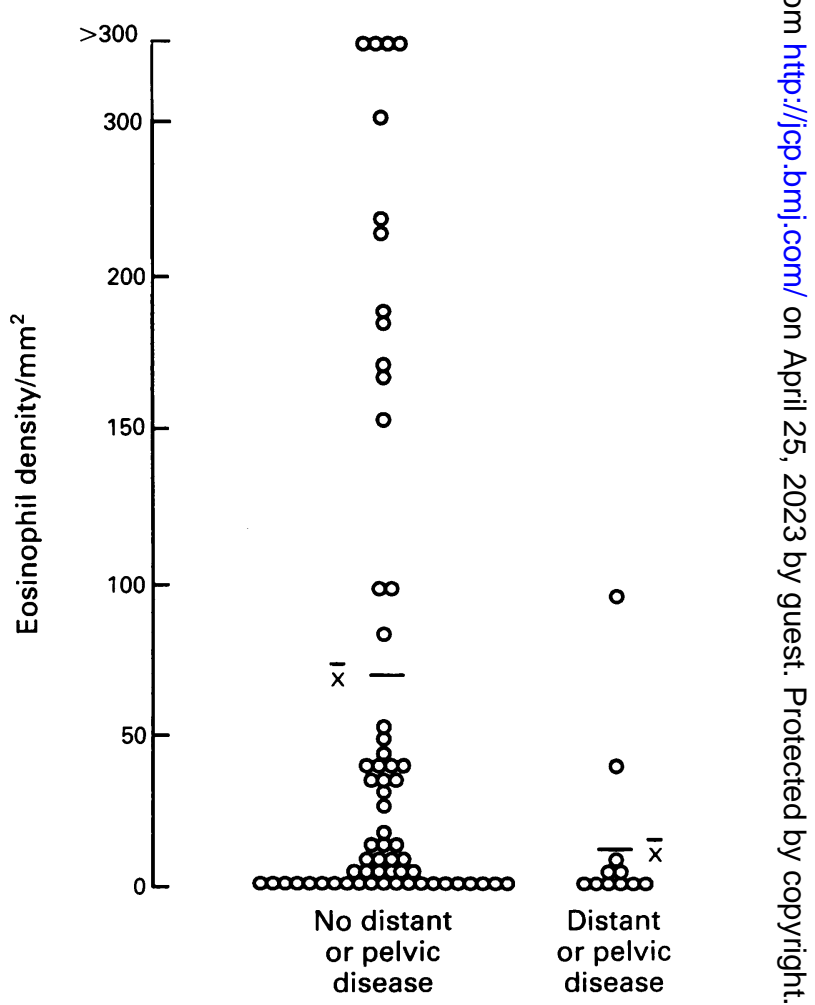

Figure 1 Ouantification of tissue associated tumour eosinophil density among cases, divided according to occurrence of subsequent distant metastatic disease or tumour recurrence (mean density marked with a bar). 


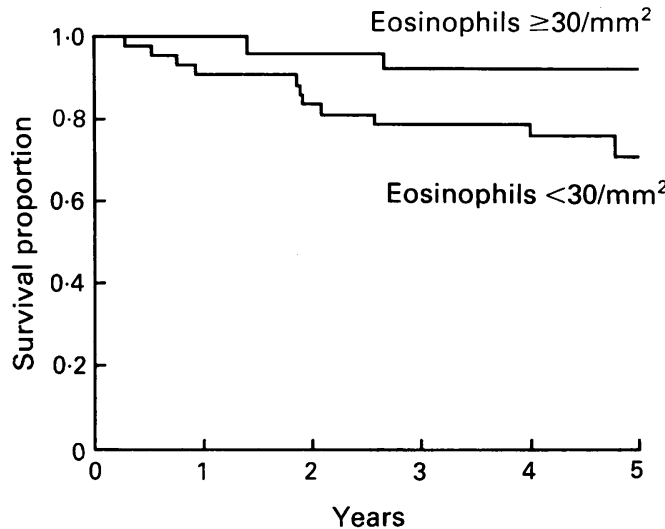

Figure 2 Five year Kaplan-Meier actuarial survival curves for women with stage IB cancer of the uterine cervix, stratified according to degree of tumour associated tissue eosinophilia.

Follow up of the series ranged from one month to 7.75 years, with a mean of 5.2 years. Thirteen women died of cervical cancer related events, the five year survival for the series being $78.9 \%$. Six women died of other causes (other malignancies $n=3$, motor vehicle accident $\mathrm{n}=2$, alcoholic liver disease $\mathrm{n}=1$ ); these intercurrent deaths were censored in the survival analysis. The crude five year survival rate for women with a tumour eosinophil density over $100 / \mathrm{mm}^{2}$ (intense TATE) was $93 \%$ compared with $75 \%$ with a density under $100 / \mathrm{mm}^{2}$, although the difference in the two survival curves was not significant (log rank $\chi^{2}$ test $1 \cdot 87, \mathrm{p}=0 \cdot 17$ ). When comparing the outcome of women with

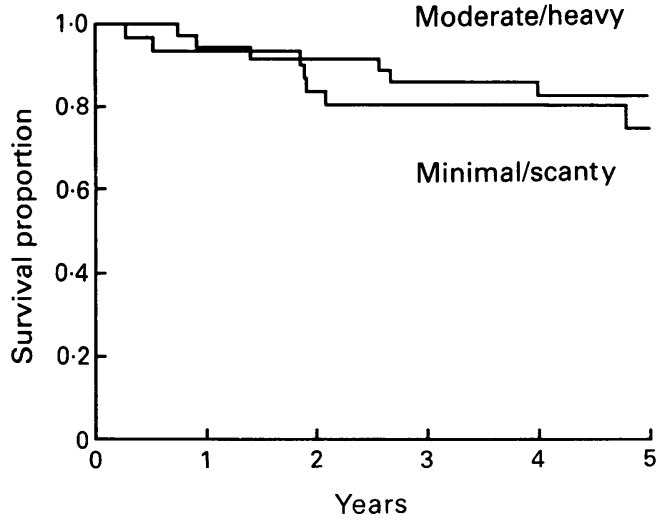

Figure 3 Five year Kaplan-Meier actuarial survival curves for women with stage IB cancer of the uterine cervix, stratified according to degree of stromal lymphocytic or plasmacytic inflammatory cell infiltration.

moderate and intense TATE $(>30$ eosinophils $/ \mathrm{mm}^{2}$ ) with the remainder, however, the survival experience was significantly different (log rank $\chi^{2}$ test $4.23, \mathrm{p}=0.03$ ). The crude five year survival rate for women with a tumour eosinophil density over $30 / \mathrm{mm}^{2}$ was $92 \%$ compared with $70 \%$ with a density under $30 / \mathrm{mm}^{2}$ (fig 2 ).

The survival of women whose tumours had minimal, rather than moderate or pronounced lymphoplamacytic stromal inflammatory response, is compared in fig 3 . While there seems to be a small difference in five year survival rates, the survival curves for these two groups of women were not significantly different ( $\log$-rank $\left.\chi^{2} 0 \cdot 64, p=0 \cdot 42\right)$.

Table 2 Summary of previous work on survival of women with cervical carcinomas demonstrating intense stromal eosinophilia.

\begin{tabular}{|c|c|c|c|c|}
\hline $\begin{array}{l}\text { Authorl } \\
\text { year }\end{array}$ & $\begin{array}{l}\text { No of } \\
\text { women/ } \\
\text { (Stage) }\end{array}$ & $\begin{array}{l}\text { No (\%) with } \\
\text { intense stromal } \\
\text { eosinophilia }\end{array}$ & $\begin{array}{l}\text { Survival with } \\
\text { intense stromal } \\
\text { eosinophilia }\end{array}$ & Conclusion \\
\hline $\begin{array}{l}\text { Ayhan et al } \\
1992^{14}\end{array}$ & $\begin{array}{l}110 \\
{[I]}\end{array}$ & $29{ }^{\star}(26)$ & $\begin{array}{l}5 \text { y survival } 86 \% \\
80 \% \text { for mild infiltration } \\
(p>0.05)\end{array}$ & $\begin{array}{l}\text { No significant } \\
\text { effect of intense } \\
\text { TATE on survival }\end{array}$ \\
\hline \multicolumn{5}{|l|}{$\begin{array}{l}\text { Lowe } \\
1988^{6}\end{array}$} \\
\hline (i) UK & $\begin{array}{l}1027 \\
\text { (all) }\end{array}$ & $34 \dagger(3 \cdot 3)$ & $\begin{array}{l}5 \text { y survival } 100 \% \\
\text { (stage 1) and } 100 \% \text { (stage 2) } \\
\text { expected from FIGO figures } \\
78 \% \text { \& } 57 \% \text {, respectively }\end{array}$ & $\begin{array}{l}\text { Suggestion of } \\
\text { improved outlook } \\
\text { compared with a } \\
\text { general unselected } \\
\text { series }\end{array}$ \\
\hline (ii) Malawi & $\begin{array}{l}431 \\
\text { (all) }\end{array}$ & $13+(3 \cdot 0)$ & & \\
\hline $\begin{array}{l}\text { Kapp } \\
\quad \text { Li Volsi } \\
1983^{4}\end{array}$ & $\begin{array}{l}417 \\
\text { (all) }\end{array}$ & $14 \ddagger(3 \cdot 4)$ & $\begin{array}{l}11 / 12(92 \%) \text { stage } \\
\text { IB/2A free of disease } \\
85 \% \text { without intense TATE } \\
\text { (follow up } 2-18 \mathrm{y})\end{array}$ & $\begin{array}{l}\text { Earlier stage } \\
\text { disease and } \\
\text { suggestion of } \\
\text { improved survival } \\
\text { with intense TATE }\end{array}$ \\
\hline $\begin{array}{l}\text { Bostram and } \\
\text { Hart } 1981^{2}\end{array}$ & $\begin{array}{l}62 \\
{[\mathrm{I}]}\end{array}$ & $\begin{array}{l}3+t(4 \cdot 5) \\
+3 \text { other } \\
\text { unsourced } \\
\text { cases }\end{array}$ & $\begin{array}{l}4 / 4(100 \%) \text { stage IB } \\
\text { free of disease } \\
\text { (follow up } 3 \mathrm{~m} 14 \mathrm{y} \text { ) } \\
1 \text { stage IIb case dead at } 2 \mathrm{y}\end{array}$ & $\begin{array}{l}\text { Survival with } \\
\text { intense TATE } \\
\text { comparable with } \\
\text { cervical cancer in general }\end{array}$ \\
\hline $\begin{array}{l}\text { Sidhu et al } \\
1970^{7}\end{array}$ & $\begin{array}{l}115 \\
{[\mathrm{I}]}\end{array}$ & $5^{\star \star}(4 \cdot 3)$ & $\begin{array}{c}4 / 5(80 \%) \text { alive at } 5 y \\
82 \% \text { for total group }\end{array}$ & $\begin{array}{l}\text { No effect of } \\
\text { intense TATE on } \\
\text { survival }\end{array}$ \\
\hline \multicolumn{5}{|l|}{$\begin{array}{l}\text { Bailar et al } \\
1966^{13}\end{array}$} \\
\hline (i) Connecticut & $\begin{array}{l}277 \\
\text { (all) }\end{array}$ & $33^{\star \star}(11.9)$ & $\begin{array}{l}5 \text { y survival } 49 \% \text { cf } 51 \% \\
\text { for remainder of series }\end{array}$ & $\begin{array}{l}\text { Suggestive but } \\
\text { not significant } \\
\text { improvement in } \\
\text { survival with } \\
\text { intense TATE }\end{array}$ \\
\hline $\begin{array}{l}\text { (ii) South West } \\
\text { England }\end{array}$ & $\begin{array}{l}358 \\
\text { (all) }\end{array}$ & $16^{\star \star}(4 \cdot 5)$ & $\begin{array}{l}5 \text { y survival } 56 \% \text { cf } 40 \% \\
\text { for remainder of series }\end{array}$ & \\
\hline
\end{tabular}

* subjective grading into mild, moderate, and intense eosinophilic infiltrate.

tstromal eosinophils $>100 / \mathrm{mm}^{2}$

feosinophils $>25 \%$ of stromal inflammatory cells.

t†subjective grading into "conspicuous" and "inconspicuous" categories

$\star \star$ "heavy stromal eosinophilia"-not otherwise defined 


\section{Discussion}

Eosinophils were characterised over 140 years ago and their presence in tissue tumour sections has been described in case reports since the turn of the century. ${ }^{19}$ This association was distinguished from tumour related blood eosinophilia, characteristic of a number of carcinomas and soft tissue tumours, and usually associated with late stage disease and widespread metastases. We now recognise that tumour related blood eosinophilia and tumour stromal eosinophilia are often independent events and that while the former is associated with a poor outlook, the latter is sometimes a predictor of a good outcome. ${ }^{8}$

Intense TATE has been extensively reported in cervical carcinoma, usually associated with invasive squamous cell carcinomas of the large non-keratinising type. ${ }^{8}$ The proportion of such tumours is variously reported to range from $3 \%$ to $26 \%$, depending on the criteria used to define "intense" eosinophilic stromal infiltration. As demonstrated in this series, the use of special techniques identifies a greater proportion of tumours with moderate TATE, which may not be conspicuous in routinely stained sections, especially if eosinophils are admixed with a dense infiltrate of lymphoctes or plasma cells.

Previous workers have investigated the prognostic effect of intense TATE in cervical carcinomas. ${ }^{2-71314}$ The results of recent series are summarised in table 2 . Because of the small number of cases with intense TATE in most series, formal survival analysis techniques have not been applied. Instead, comments on the prognostic effect of intense TATE have been confined to comparing, either with or without a parametric statistical test, the crude five year survival rate of this group with the remainder. Three of the six studies undertaken since 1965 suggest that intense tumour stromal eosinophilia is associated with an improved crude five year survival, the remainder concluding there is no survival advantage. The current study is the first to use formal survival analysis techniques combined with quantification of the stromal eosinophilia, demonstrating a significantly improved survival associated with lesser degrees of eosinophilic infiltration than assessed before.

In our data there is, not surprisingly, a strong correlation between the degree of stromal eosinophil and lymphoplasmacytic cell infiltration (table 1). This latter variable has been shown to be associated with improved survival and there may be some confounding by this effect in our eosinophil survival data. In our data, however, an eosinophilic infiltrate predicts a significantly improved survival, while a lymphoplasmacytic infiltrate does not, although the former variable was assessed more rigorously than the latter.

Eosinophils kill a wide range of helminthic parasites, especially in their larval stage, and there is a body of experimental work which shows that eosinophils can kill tumour cells in vitro, ${ }^{19}$ possibly through the release of cationic proteins ${ }^{20}$ and the generation of toxic hypohalous acids by eosinophil peroxidase. ${ }^{21}$ In addition, eosinophils synthesise CD4 and HLA-DR and may act as antigen presenting cells and stimulate local immune reactions. ${ }^{21}$ Furthermore, stromal eosinophilia potentiates the effect of radiation treatment. Dalal and coworkers have shown that a cervical tumour stromal eosinophilia of over 20 cells $/ \mathrm{mm}^{2}$ is associated with a significantly better tumour radiation response, as defined by a greater than $50 \%$ reduction in tumour size following treatment. ${ }^{3}$ They hypothesise this may be an effect of the induction of tissue oedema by eosinophil products, with enhancement of radiation damage through increased free radial formation.

The factors which determine the variability in tumour stromal eosinophilia are unknown. In this study no difference was noted in eosinophil density between small and large tumours, defined either by surface dimension or depth of invasion. Tumour necrosis, as exemplified by the phenomenon of post irradiation eosinophilia, may be a factor, although tumour necrosis was not a conspicuous feature in most cases examined in this series. Recent interest has centred on variable tumour oestrogen receptor phenotypes, with one receptor type appearing to show increased binding to eosinophils. ${ }^{3}$ Further work to define this and other cytokine mediated differences in cervical eosinophil recruitment is needed.

Many factors have been identified as having prognostic value in women with low stage cervical carcinoma, including tumour size, depth of invasion, lymphatic spread, vascular space invasion, occult tumour mucin production and local recurrence following primary treatment. ${ }^{15}$ The current study has not examined stromal eosinophilia in relation to these other variables, an exercise which would require larger numbers for meaningful multivariate analysis. But we have shown that, as a univariate parameter, a stromal eosinophilia of at least modest proportions is associated with a significantly improved survival in stage IB carcinomas. We do not advocate formal quantification of tumour stromal eosinophil infiltration in routine assessment of invasive cervical carcinomas. Our current practice is to examine several high magnification fields in haematoxylin and eosin stained sections, and where more than a scattered eosinophil is present, roughly corresponding to at least our moderate TATE group, we append a comment to the histology report along with the other routinely described prognostic indices.

1 Underwood J. Lymphoreticular infiltration in human tumours: prognostic and biological implications: review. Br f Cancer 1974;30:538-48.

2 Bostrom SG, Hart WR. Carcinomas of the cervix with intense stromal eosinophilia. Cancer 1981;47:2887-93.

3 Dalal BI, Das KC, Dutta TK, Malakar, K. Local and systemic eosinophilia in patients with carcinoma of the uterine cervix undergoing radiation therapy: correlation with radiation response. Clin Oncol 1992;4:18-21.

4 Kapp D, LiVolsi V. Intense eosinophilic stromal infiltration in carcinoma of the uterine cervix: a clinicopathological study of 14 cases. Gynaecol Oncol 1983;16:19-30. 
5 Lowe D, Jorizzo J, Hutt M, Chiphangwi, J. Cervical carcinoma in Malawi: a histopathological study of 460 cases. Cancer 1981;47:2493-5.

6 Lowe D. Carcinoma of the cervix with massive eosinophilia. Br f Obstet Gynaecol 1988;95:393-401.

7 Sidhu G, Koss L, Barber H. Relation of histologic factors to the response of Stage I epidermoid carcinoma of the cervix to surgical treatment: analysis of 115 patients. Obstet Gynaecol 1970;35:329-38.

8 Lowe D, Jorizzo J, Hutt M. Tumour-associated eosinophilia: a review. $\mathcal{F}$ Clin Pathol 1981;34:1342-8

Healy T. Eosinophilia in bronchogenic carcinoma. $N$ Engl f Med 1974;291:794.

10 Iwasaki K, Torisu M, Fujimura T. Malignant tumour and eosinophils: I Prognostic significance in gastric cancer. Cancer 1986;58:1321-7.

11 Pretlow TP, Keith EF, Cryar AK, et al. Eosinophils infiltration of human colonic carcinomas as a prognostic tration of human colonic carcinomas as a prognostic

12 indicator. Clancer Res 1983,43.2997-3000.

Lowe D, Flecher C, Gow associated eosinophilia in urinary bladder. F Clin Pathol 1984;37 500-2

13 Bailar J, Thomas L, Thomson A, Eisenberg H, Vick R. Morphology and survival rates of cervical cancer in Connecticut and Southwest England. NCI Monograph 1966;19:385-403.

14 Ayhan A, Altintas A, Tuncer Z, Kucukali T, Yuce K.
Prognostic value mitotic activity, eosinophilic and inflammatory reaction in stage $I$ cancer of the uterine cervix. Eur $\mathcal{f}$ Surg Oncol 1992;18:264-6.

15 Bethwaite PB, Yeong ML, Holloway LJ, Robson B, Duncan G, Lamb D. The prognosis of adenosquamous carcinomas of the uterine cervix. Br $\mathcal{f}$ Obstet Gynaecol carcinomas of the

16 Hsu S, Raine L, Fauger H. Use of avidin-biotin-peroxidase complex $(\mathrm{ABC})$ in immunoperoxidase techniques: a comparison between $\mathrm{ABC}$ and unlabelled antibody (PAP) procedures. $\mathcal{F}$ Histochem Cytochem 1981;29: 557-80.

17 Kaplan E, Meier P. Nonparametric estimation from incomplete observations. F Am Stat Assoc 1958;53: 457-81.

18 Lamb D, Duncan G, Symons L, Johnson AD, Gray AJ. Results of treatment of cancer of the cervix in Wellington 1980-84. New Zealand Med $f$ 1990;103: 526-8.

19 Spry C. Eosinophils: a comprehensive review, and guide to the scientific and medical literature. Oxford: Oxford University Press, 1988.

20 Gleich G, Frigas E, Loegering D, Wassom DL, Steinmuller D. Cytoxic properties of the eosinophil major basic protein. F Immunol 1979;123:2925-7.

21 Weller P. The immunobiology of eosinophils. $N$ Engl f 